\title{
Pro-inflammatory cytokines and adipose tissue
}

\author{
Simon W. Coppack \\ Academic Medical Unit, St Bartholomew's and The Royal London School of Medicine, Whitechapel, London E1 1BB, UK
}

\begin{abstract}
Cytokines appear to be major regulators of adipose tissue metabolism. Therapeutic modulation of cytokine systems offers the possibility of major changes in adipose tissue behaviour. Cytokines within adipose tissue originate from adipocyte, preadipocyte and other cell types. mRNA expression studies show that adipocytes can synthesise both tumour necrosis factor $\alpha$ (TNF- $\alpha$ ) and several interleukins (IL), notably IL-1 $\beta$ and IL-6. Other adipocyte products with 'immunological' actions include complement system products and macrophage colony-stimulating factor. Cytokine secretion within adipocytes appears similar to that of other cells. There is general agreement that circulating TNF- $\alpha$ and IL- 6 concentrations are mildly elevated in obesity. Most studies suggest increased TNF- $\alpha$ mRNA expression or secretion in vitro in adipose tissue from obese subjects. The factors regulating cytokine release within adipose tissue appear to include usual 'inflammatory' stimuli such as lipopolysaccaride, but also the size of the fat cells per se and catecholamines. There is conflicting data about whether insulin and cortisol regulate TNF- $\alpha$. The effects of cytokines within adipose tissue include some actions that might be characterised as metabolic. TNF- $\alpha$ and IL-6 inhibit lipoprotein lipase, and TNF- $\alpha$ additionally stimulates hormone-sensitive lipase and induces uncoupling protein expression. TNF- $\alpha$ also down regulates insulin-stimulated glucose uptake via effects on glucose transporter 4, insulin receptor autophosphorylation and insulin receptor substrate-1. All these effects will tend to reduce lipid accumulation within adipose tissue. Other effects appear more 'trophic', and include the induction of apoptosis, regulation of cell size and induction of de-differentiation (the latter involving reduced peroxisome proliferator-activated receptor $\gamma$ ). Cytokines are important stimulators and repressors of other cytokines. In addition, cytokines appear to modulate other regulatory systems. Examples of the latter include effects on leptin secretion (probably stimulation followed by inhibition) and reduction of $\beta_{3}$-adrenoceptor expression. There seems to be no clear agreement as to which cytokines derived from adipose tissue act as remote regulators, i.e. hormones. Leptin, which is structurally a cytokine, is also a hormone. IL- 6 appears to be released systemically by adipose tissue, but TNF- $\alpha$ is probably not. Both leptin and IL-6 appear to act on the hypothalamus, IL-6 acts on the liver, while leptin may have actions on the pancreas. The importance of the immune system in whole-body energy balance provides a rationale for the links between cytokines and adipose tissue. It seems clear that TNF- $\alpha$ is a powerful autocrine and paracrine regulator of adipose tissue. Other cytokines, notably leptin, and possibly IL-6, have lesser actions on adipose tissue. These cytokines act as hormones, reporting the state of adipose tissue stores throughout the body.
\end{abstract}

Cytokines: Adipose tissue: Tumour necrosis factor $\alpha$ : Interleukin 6: Leptin

Cytokines have been described (McDermott, 2001) as 'A vast array of relatively low molecular weight, pharmacologically active proteins that are secreted by one cell for the purpose of altering either its own functions (autocrine effect) or those of adjacent cells (paracrine effect). In many instances, individual cytokines have multiple biological activities. Different cytokines can have the same activity, which provides for biological redundancy within the inflammatory and immune systems. As a result, it is infrequent that loss or neutralization of one cytokine will markedly interfere with either of these systems. This fact has great significance in the development of therapeutic strategies.' Over 200 cytokine ligands have been recognised. With regard to adipose tissue, only a handful of 
these cytokines have been studied, notably tumour necrosis factor (TNF) $\alpha$ and various interleukins (IL) including IL-1 $\beta$, IL-6 and IL-8. Fortunately, there appears to be a hierarchy of cytokines, so that some of the 'higher order' cytokines, such as TNF- $\alpha$, orchestrate the synthesis, secretion and activity of others.

The present review will address: (1) the regulation of cytokine production in adipose tissue; (2) the effects of cytokines within adipose tissue; (3) the possible role of cytokines as remote signals from adipose tissue.

The different 'families' of cytokines have characteristic protein structures for the ligands and receptors. Leptin and its receptor have been shown to have structures resembling pro-inflammatory cytokines and receptors respectively. As leptin has a structural relationship with pro-inflammatory cytokines, the present review will allude to leptin as a possible indicator of the way such cytokines behave.

\section{Cytokine production in adipose tissue and its regulation}

White adipocytes per se, especially those in subcutaneous tissue, are the main source of leptin from adipose tissue (Montague et al. 1998). However, approximately $50 \%$ of the nuclei and protein synthetic components in adipose tissue are found in non-adipocyte cells such as immunocytes, vascular, stromal and other cells which are also able to synthesise cytokines. For TNF- $\alpha$, the most-studied cytokine in adipose tissue, it has been shown that most of the mRNA in adipose tissue is found within adipocytes per se (Hotamisligil et al. 1993; Kern et al. 1995; Montague et al. 1998). However, mRNA abundance is very low compared with that of other proteins in human white adipocytes (Montague et al. 1998) and unstimulated adipose tissue releases relatively small amounts of TNF- $\alpha$ in vitro (Crawford et al. 1997).

IL-6 is another pro-inflammatory cytokine secreted by adipose tissue in culture (Purohit et al. 1995; Fried et al. 1998), and its mRNA has also been demonstrated within adipocytes (Stephens et al. 1992; Purohit et al. 1995; Fried et al. 1998; Bastard et al. 2000). However, for IL-6 and other cytokines there is still uncertainty as to the proportion of the total tissue cytokine production that comes from adipocytes per se. For example, Fried et al. (1998) reported that isolated adipocytes release only $10 \%$ as much IL-6 as adipose tissue in culture.

This sort of quantification is made more complex by the mechanisms by which cytokines can be secreted. For example, TNF- $\alpha$ is secreted as a membrane-bound precursor (26 kDa, 233 amino acids) (Gearing et al. 1994; McDermott, 2001). Acting on the membrane-bound substrate, a matrix metalloproteinase known as TNF- $\alpha$ converting enzyme cleaves off soluble TNF- $\alpha$ which has 157 amino acids (17 kDa) (Gearing et al. 1994; Fried et al. 1998).

Once generated, membrane-bound TNF- $\alpha$ and soluble TNF- $\alpha$ in man can interact with receptors such as TNF receptors (TNF-R) 1 and 2 . In man these are known as gp60 or TNFR60 and gp80 or TNFR80 respectively). In mice, the p55 receptor corresponds to TNF-R1 and p75 receptor to TNF-R2. Adipose tissue expresses mRNA for both these two receptors (Hotamisligil et al. 1997).
TNF- $\alpha$ and its main receptors also form part of a superfamily of related cytokines and receptors (McDermott, 2001). It is known that in other (non-adipose) tissues there are nineteen different ligands that can interact with TNF receptors and that TNF- $\alpha$ can interact with a total of over twenty receptors (McDermott, 2001). It is unclear to what extent other members of these superfamilies are active in adipose tissue. However, of the major TNF receptors that are known to be active in adipose tissue, TNF-R1 mediates apoptosis, whilst TNF-R2 induces one or more mitogenassociated protein kinases (Hube \& Hauner, 1999). There is no clear consensus as to how the different receptors relate to different actions of TNF- $\alpha$. Pharmacological studies concluded that the TNF-R2 was involved with induction of insulin resistance (Hube \& Hauner, 1999), although studies with knockout animals suggested that the TNF-R1 is crucial for stimulating lipolysis (Sethi et al. 2000). Whilst it is clear that membrane-bound TNF- $\alpha$ can interact with both TNFR1 and TNF-R2, it has been suggested that soluble TNF- $\alpha$ preferentially binds to TNF-R1 rather than TNF-R2 (Hube \& Hauner, 1999). More recently, it has been suggested that there are $60 \mathrm{kDa}$ proteins that bind TNF- $\alpha$ in the mitochondria, the significance of which is undetermined as yet (Ledgerwood et al. 1998).

TNF- $\alpha$ synthesis within adipose tissue has been more extensively studied than that of other cytokines. Its production can be shown to be responsive to both 'nutritional' and 'immunological' regulators. Additionally, there are regional effects such that subcutaneous adipose tissue expresses mRNA for TNF- $\alpha$ and TNF-R1 and TNF-R2 to a greater extent than omental tissue (Hube et al. 1999a). The reverse is true for IL-6 mRNA (Fried et al. 1998).

\section{Regulation by nutritional factors}

The synthesis of TNF- $\alpha$ can be shown to be related both to adiposity and to fatty acid metabolism. In many situations, adiposity and fatty acid metabolism are themselves linked. Several studies demonstrate that obese animals have increased TNF- $\alpha$ mRNA and protein synthesis within adipose tissue, as reviewed by Hotamisligil (1999). While mRNA expression is higher in obese human subjects (Hotamisligil et al. 1995; Hotamisligil, 1999; Hube et al. $1999 \mathrm{a})$, it is not clear whether the protein release in vitro shows the same trend (Sewter et al. 1999). Circulating concentrations of TNF- $\alpha$ are usually reported to be slightly greater in more obese subjects (Hotamisligil et al. 1995; Mohamed-Ali et al. 1997), but the correlation between adiposity and plasma TNF- $\alpha$ is relatively weak, typically $r_{s}$ $<0 \cdot 40$; Mohamed-Ali et al. 1997; Hauner et al. 1998) and some researchers do not report this effect in human subjects (Hauner et al. 1998). Weight loss reduces plasma TNF- $\alpha$ and IL-6 concentrations (Kern et al. 1995; Bastard et al. 2000), whilst feeding animals high-fat diets will increase the TNF- $\alpha$ content of their adipose tissue (Morin et al. 1997b). Both adiposity and adipose tissue TNF- $\alpha$ increase as rats age (Morin et al. 1997a). Transgenic animals with the adipocyte fatty acid-binding protein knocked out of their adipose tissue have no TNF- $\alpha$ in their adipose tissue (Hotamisligil et al. 1996a). n-3 Fatty acids reduce production, as does infusion of Intralipid (Nisoli et al. 
$2000 b$ ). Insulin stimulates adipose tissue to produce more TNF- $\alpha$, although the effect is less obvious in isolated adipocytes (Sewter et al. 1999). Circulating TNF- $\alpha$ concentration tends to correlate with circulating insulinaemia (Hotamisligil et al. 1995), although this relationship is difficult to interpret in view of the close inter-correlation of obesity and insulinaemia. Thiazolidinediones have been reported to stimulate adipose tissue TNF- $\alpha$ production in lean human subjects (Sewter et al. 1999), but to depress it in obese rodents (Peraldi et al. 1997a).

\section{Regulation by immunological factors}

In macrophages and monocytes many immunological regulators are known to affect cytokine production. Endotoxin induces TNF- $\alpha$ mRNA expression (Berkowitz et al. 1998) and protein secretion from both adipose tissue and isolated adipocytes within $2 \mathrm{~h}$ (Berkowitz et al. 1998; Sewter et al. 1999). Stimulation of TNF- $\alpha$ protein synthesis in vitro by lipopolysaccharide can be blocked by inhibitors of metalloproteinases (Sewter et al. 1999). Phorbol esters and phosphatase inhibitors induce TNF- $\alpha$ production in adipose tissue. Cortisol has no significant effect on adipose tissue TNF- $\alpha$ production, although it depresses production by macrophages (Beutler et al. 1986; Sewter et al. 1999). By contrast, glucocorticoid reduces adipose tissue IL-6 release in vitro (Fried et al. 1998).

TNF- $\alpha$ is able to induce not only its own synthesis, but is also a powerful regulator of other cytokines, e.g. stimulating the production of IL-6 (Stephens \& Pekala, 1991). TNF- $\alpha$ may also regulate the synthesis of its own receptors. The expression of the TNF-R1 receptor may (Hube et al. 1999a) or may not (Hotamisligil et al. 1997) correlate with adiposity. Expression of the TNF-R2 receptor may correlate more closely with adipocyte diameter (Hube et al. 1999a) or obesity (Hotamisligil et al. 1997). These associations notwithstanding, in general the synthesis of TNF receptor mRNA within adipose tissue appears to be linked with that of TNF- $\alpha$ (Hube et al. 1999a), although this area has not been extensively studied. Little is known about deactivation of TNF and IL-6 receptors, but metalloproteinases cleave them from the cell surface (Mullberg et al. 1995).

\section{Effects of cytokines within adipose tissue}

For purposes of discussion, cytokines may be considered as having 'metabolic' effects, 'trophic' effects and effects on other regulatory systems within adipose tissue, although patently such divisions are somewhat artificial and arbitrary, and do not reflect physiology.

As discussed earlier, there is still uncertainty about which TNF- $\alpha$ receptor mediates individual effects of the cytokine within adipose tissue. It is known that a variety of cytoplasmic and nuclear 'second messengers' are involved in the TNF- $\alpha$ signal transductions. Within adipose tissue these messengers include CCAAT-enhancer-binding proteins $\alpha$ and $\beta$, the sphingomyelinase leading to the generation of ceramide and the proliferative and cell growth regulating p44/42 mitogen-associated protein kinase cascade (Jain et al. 1998, 1999). This topic has been authoritatively reviewed by Qi \& Pekala (2000).

\section{Metabolic effects of cytokines}

There are more data relating to the metabolic actions of TNF- $\alpha$ than those of other cytokines (Table 1). Most of these effects have been demonstrated by in vitro studies of rodent adipose tissue. In these studies TNF- $\alpha$ can reduce expression of mRNA for glucose transporter 4 (Stephens \& Pekala, 1991) as well as stimulate hormone-sensitive lipase expression to increase lipolysis (Sumida et al. 1997). TNF- $\alpha$ has long been known to decrease lipoprotein lipase activity (Kawakami et al. 1982; Fried \& Zechner, 1989; Feingold \& Grunfeld, 1992). The net effect is to induce insulin resistance and mobilise lipids (Ogawa et al. 1989; Hauner et al. 1995) from within the adipocytes. TNF- $\alpha$ appears to orchestrate these effects via inhibition of CCAAT-enhancerbinding protein (Stephens \& Pekala, 1991) and peroxisome proliferator-activated receptor $\gamma$ (Zhang et al. 1996). This suppression may down regulate many adipocyte-specific proteins such as fatty acid-binding protein, fatty acid synthase, acetyl-CoA carboxylase and glucose-6-phosphate dehydrogenase as well as lipoprotein lipase and glucose transporter 4 (Hube \& Hauner, 1999). TNF- $\alpha$ also reduces tyrosine phosphorylation of the insulin receptor and increases phosphorylation of insulin receptor substrate-1 at serine residues, actions which contribute to the insulinresistant state.

TNF- $\alpha$ can also inhibit insulin action and insulin receptor signalling in cultured human adipocytes (Liu et al. 1998). This inhibition of insulin action is thought to be mainly mediated by TNF-R1 (Kanety et al. 1996; Peraldi et al. 1997b). Administration of a soluble TNF-Rimmunoglobulin $\mathrm{G}$ fusion protein improved insulin sensitivity in obese rodents in vivo (Hotamisligil et al. 1993). However, attempts to demonstrate the importance of TNF- $\alpha$ in human subjects in vivo by infusion of anti-TNF- $\alpha$ antibodies showed no effect (Ofei et al. 1996). It is not clear whether this finding should be interpreted as showing that TNF- $\alpha$ has no metabolic effects in man. Alternative explanations might be that the antibody concentrations and binding characteristics were not adequate, or that they were not able to penetrate the tissues to adequately block both membrane-bound TNF- $\alpha$ and soluble TNF- $\alpha$.

IL-6 and IL-1 $\beta$ also reduce adipose tissue lipoprotein lipase activity (Feingold et al. 1992; Greenberg et al. 1992; Hardardottir et al. 1994).

\section{Trophic effects of cytokines}

The trophic effects of TNF- $\alpha$ have been studied more extensively than those of the other cytokines. In mature white adipocytes TNF- $\alpha$ is reported to regulate cell size (Hotamisligil et al. 1995), the suggestion being that as the cells get bigger they produce more TNF- $\alpha$, which in turn initiates changes to limit adipocyte size or to induce apoptosis.

The regulation of adipose cell numbers is complex, with regulation occurring through multiple mechanisms (Prins \& O'Rahilly, 1997). However, TNF- $\alpha$ may be a major factor, with actions on both adipocyte precursors and mature adipocytes. There are three main ways in which cell numbers can be regulated within adipose tissue: 
(1) blocking differentiation of new adipocytes; (2) promoting de-differentiation of existing adipocytes or preadipocytes; (3) inducing apoptosis of adipocytes or preadipocytes. TNF- $\alpha$ appears to do all three, at least in vitro. TNF- $\alpha$ has been shown to induce apoptosis in preadipocytes (Prins et al. 1997), with omental preadipocytes more sensitive to this effect than subcutaneous preadipocytes (Niesler et al. 1998). Additionally, it can both block differentiation and induce de-differentiation in preadipocytes (Pekala et al. 1983; Torti et al. 1989; Petruschke $\&$ Hauner, 1993). TNF- $\alpha$ can induce both de-differentiation (Petruschke \& Hauner, 1993), and also apoptosis of mature adipocytes (Prins et al. 1997). Prins et al. (1997) demonstrated a dose-response effect, with a maximal effect at $25 \mathrm{nM}-\mathrm{TNF}-\alpha$ and an effect within $2 \mathrm{~h}$.

In brown adipocytes TNF- $\alpha$ appears to have the slightly 'contradictory' actions of both mediating apoptosis and stimulating uncoupling protein-1 expression (Nisoli et al. $2000 b)$.

Insulin-like growth factor-1 potentiates the pro-apoptotic effect of TNF- $\alpha$ (Niesler et al. 2000), but thiazolidinediones can block the effects of TNF- $\alpha$ on regulation of adipocyte number (Szalkowski et al. 1995).

\section{Cytokine effects on other regulators}

In addition to the previously described metabolic and trophic effects, cytokines can also have important actions via their impact on other regulators. These actions include the abilities of cytokines to affect signals coming into adipose tissue. An example of this effect is the ability of TNF- $\alpha$ to repress the expression of $\beta_{3}$-adrenoceptors in white and brown adipocytes (Berkowitz et al. 1998; Nisoli et al. 2000a). These receptors are important for sympathetically-mediated lipolysis in white adipose tissue and thermogenesis in brown adipose tissue (Strosberg \& Pietri-Rouxel, 1996). TNF- $\alpha$ can also regulate signals efferent from adipose tissue by inducing leptin mRNA expression in, and protein secretion from, adipocytes (Grunfeld et al. 1996; Kirschgessner et al. 1997; Berkowitz et al. 1998). A complication of this effect is that it is not seen during longer incubations of fat cells, but the reason for this situation has not been established (Fawcett et al. 2000). Exogenous IL-1 is also able to stimulate leptin secretion (Sarraf et al. 1997).

\section{Knockout animals}

Transgenic animals have been bred with TNF- $\alpha$ protein (Uysal et al. 1997; Ventre et al. 1997) or its receptors (Uysal et al. 1998) knocked out. The TNF- $\alpha$ protein knockout animals are the same weight as their wild-type littermates when placed on equivalent diets (Uysal et al. 1997). They have low plasma concentrations of insulin and of nonesterified fatty acids (Uysal et al. 1997; Ventre et al. 1997). These animals have increased insulin sensitivity, this change being mediated through rodent TNF-R1 (Uysal et al. 1997; Hotamisligil, 1999). The rodents with TNF receptors knocked out similarly have normal adiposity, but also show better insulin sensitivity even when obese (Uysal et al. 1998).

\section{Questions about the importance of cytokines in adipose tissue}

If we are to consider that cytokines are important regulators within adipose tissue, we need to be sure that cytokines have the proposed regulatory effects at concentrations (or 'doses') actually found in adipose tissue. Many actions of cytokines listed earlier have been demonstrated at concentrations which may be much greater than those known to exist in adipose tissue. The fact that TNF- $\alpha$ knockout animals do have abnormal insulin resistance and lipid metabolism suggests that cytokines have constitutive effects under physiological conditions (Uysal et al. 1997; Ventre et al. 1997). However, these animals apparently had normal adiposity. This factor would suggest either that TNF- $\alpha$ has only a minor role on adipose tissue mass, or that the redundancy of the system for adipose tissue regulation is such that removing TNF- $\alpha$ as a single factor has little impact.

There is evidence that at least some cytokines do not have the same effects in different adipose tissue depots or adipocytes. There is the possibility that the effects of cytokine on adipose tissue differ between species (Hube \& Hauner, 1999), but this factor has not been extensively studied. Even within one mammal, different adipose depots show different responses to cytokines and levels of cytokine expression (Fried et al. 1998; Hube et al. 1999b). Furthermore, there is data that preadipocytes and mature adipocytes can differ in their cytokine expression characteristics (Hube et al. 1999b). Finally, except for the knockout animals, all the other studies have examined short-term effects of cytokines, and we know little of the longer-term actions of cytokines on adipose tissue. Indeed, there is some evidence that TNF- $\alpha$ can have a biphasic action on leptin secretion, with intial stimulation being followed by suppression (Fawcett et al. 2000).

\section{Tumour necrosis factor $\alpha$ as an anti-adipogenic regulator}

Notwithstanding these limitations in the current state of knowledge, it has been postulated that TNF- $\alpha$ acts as a regulator of adipose tissue mass through its anti-adipogenic effects (Hube \& Hauner, 1999). TNF- $\alpha$ has a wide range of actions which all combine to reduce adiposity. Some of these effects are listed in Table 1.

Many of these actions have been mentioned earlier and extend from actions within adipose tissue to remote effects on appetite. Induction of uncoupling protein-1 would tend to promote 'wasting' of energy by uncoupled respiration. Naturally, such energy wastage will tend to reduce the size of adipose tissue stores. The propensity of TNF- $\alpha$ to prevent both differentiation of preadipocytes and promotion of apoptosis within mature adipocytes will tend to reduce adipocyte number. Finally, TNF- $\alpha$ production in adipose tissue can potentially have effects on distant tissues either directly by TNF- $\alpha$ acting as a hormone, or indirectly by TNF- $\alpha$ affecting other hormones such as leptin.

\section{Do cytokines act as hormones from adipose tissue?}

The discovery of leptin, which is undoubtedly a hormone released by adipose tissue (Zhang et al. 1994; Friedman, 
Table 1. Some actions of tumour necrosis factor $\alpha$ as an anti-adipogenic agent

\begin{tabular}{|c|c|c|}
\hline & Examples & References \\
\hline \multirow{8}{*}{$\begin{array}{l}\text { Local metabolic actions: } \\
\text { induction of insulin resistance }\end{array}$} & Reduces expression of GLUT4 & Stephens \& Pekala (1991) \\
\hline & Stimulates HSL expression to increase lipolysis & Sumida et al. (1997) \\
\hline & Decreases LPL activity & $\begin{array}{l}\text { Kawakami et al. (1982), Fried \& Zechner (1989), } \\
\text { Feingold \& Grunfeld (1992) }\end{array}$ \\
\hline & Reduced insulin signalling: & \\
\hline & $\begin{array}{l}\text { Reduced tyrosine phosphorylation of insulin } \\
\text { receptor }\end{array}$ & Hotamisligil et al. (1994) \\
\hline & Increased phosphorylation of IRS-1 & Hotamisligil et al. (1996b) \\
\hline & Decreased C/EBP & Stephens \& Pekala (1991) \\
\hline & Decreased PPAR $\gamma$ & Zhang et al. (1996) \\
\hline \multirow[t]{2}{*}{ Local trophic actions } & Apoptosis of mature white adipocytes & \\
\hline & De-differentiation of preadipocytes & \\
\hline $\begin{array}{l}\text { Local effects on other signalling } \\
\text { systems }\end{array}$ & $\begin{array}{l}\text { Reduces expression of } \beta_{3} \text {-adrenoceptors in } \\
\text { white and brown adipocytes }\end{array}$ & Berkowitz et al. (1998), Nisoli et al. (2000a) \\
\hline Energy 'wasting' & Induction of uncoupling protein-1 & Nisoli et al. (2000a) \\
\hline Remote actions & Anorectic actions & Van der Poll et al. (1991), Plata-Salaman (2000) \\
\hline Indirect actions & $\begin{array}{l}\text { Anti-adipogenic actions via stimulation of leptin } \\
\text { production }\end{array}$ & Grunfeld et al. (1996), Sarraf et al. (1997) \\
\hline
\end{tabular}

GLUT4, glucose transporter 4; HSL, hormone-sensitive lipase; LPL, lipoprotein lipase; IRS-1, insulin receptor substrate-1; C/EBP, CCAATenhancer-binding protein; PPAR $\gamma$, peroxisome proliferator-activated receptor $\gamma$.

2000), demonstrated unequivocally that adipose tissue can act as an endocrine organ (Mohamed-Ali et al. 1998; Lawrence \& Coppack, 2000). More importantly for the present article, leptin appears to be strongly related in a structural way to pro-inflammatory cytokines. This factor clearly raises the question as to whether other cytokines can behave as hormones. Interest has focused on TNF- $\alpha$ and IL-6. For TNF- $\alpha$ it is clear that this cytokine has actions in several organs and tissues in vitro, and that it is able to induce insulin resistance by multiple effects on insulin signalling (Hotamisligil, 1999). Injections of TNF- $\alpha$ to mimic the order of circulating TNF- $\alpha$ concentrations seen in sepsis have an anorectic effect (as mentioned earlier; Van der Poll et al. 1991; Plata-Salaman, 2000) and induce elevations in plasma non-esterified fatty acid concentrations and whole-body insulin resistance (Hotamisligil, 1999). Likewise injections of IL-6 can increase circulating concentrations of fatty acids, C-reactive protein and fibrinogen (Strassmann et al. 1993). IL-1 and IL-6 are two of the several cytokines shown to have anorectic effects on the brain (Plata-Salaman, 2000) and to induce gastric stasis.

However, there is little evidence of net release of TNF- $\alpha$ from human subcutaneous adipose tissue (Mohamed-Ali et al. 1997, 1999), and injection of TNF- $\alpha$-neutralising antibody (Ofei et al. 1996) has no measurable effect on systemic insulin resistance and lipids. The fact that adipose tissue is actually a net exporter of soluble TNF-R1 (Mohamed-Ali et al. 1999) suggests that TNF- $\alpha$ produced locally within adipose tissue is sequestered, possibly by the large excess of TNF receptors within the tissue. As a result of the local production of soluble receptors, TNF- $\alpha$ ligand:soluble receptors is lower in venous blood draining subcutaneous adipose tissue than in arterial blood (Mohamed-Ali et al. 1999). Likewise, obese subjects have lower circulating TNF- $\alpha$ :soluble TNF receptors (Hauner et al. 1998; Mohamed-Ali et al. 1999). Any release into the circulation of TNF- $\alpha$ produced in adipose tissue is probably balanced by comparable clearance of circulating TNF- $\alpha$ by the same tissue.

For IL-6, a stronger case can be made for it having a role as a circulating hormone (Jones, 1994; Yudkin et al. 2000). As for TNF- $\alpha$, IL-6 injected systemically has significant effects on a variety of tissues, suppressing appetite, increasing lipolysis and suppressing lipoprotein lipase. Additionally, it is a powerful regulator of the hypothalamus-pituitary-adrenal axis (Jones \& Kennedy, 1993; Rothwell, 1994; Papanicolaou et al. 1998). As the protein is thought to be little expressed within the central nervous system, it can be inferred that IL-6 acts remotely in this way. IL-6 concentrations correlate well with concentrations of C-reactive protein, even in apparently-healthy subjects without an obvious infection (Mohamed-Ali et al. 1997, 1999). This finding suggests that IL-6 may have actions on the liver to stimulate the secretion of acute-phase proteins (Mohamed-Ali et al. 1998). IL-6 can also affect steroid hormone conversion, changing the balance of sex hormones, which is well known to regulate adipose tissue distribution (Purohit et al. 1995). The correlation of circulating IL-6 concentrations with adiposity appears stronger than those of TNF- $\alpha$ (Mohamed-Ali et al. 1997). This finding implies that a higher proportion of circulating IL-6 is synthesised by adipose tissue.

\section{Interactions between adipose tissue stores and immunology}

It is apparent that extremely-malnourished individuals have impaired immune function. Even in better-nourished individuals there are several indications of interaction between the immune system and adipose tissue. Adipose 
tissue secretes into the general circulation several factors that might appear to be predominantly involved with immune functions. One example of this action is the secretion of complement components, some of which make adipsin, a component of adipocyte-stimulating protein (Saleh et al. 1998). Another example is the secretion of IL-6 discussed earlier. IL-6 appears to act as both a proinflammatory cytokine and as an important hypothalamic regulator (Jones \& Kennedy, 1993; Rothwell, 1994). This fact may give a clue to the ontological development of leptin, a hormone with a cytokine structure having major effects on the hypothalamus but whose relation to inflammation appears to be somewhat peripheral. Pond, whose work is described elsewhere in the present symposium (Pond, 2001), has shown that there is a tight coupling of adipocyte metabolic activity with their distance to the nearest lymph node (Pond, 1999), and that TNF- $\alpha$, and IL-4 and IL-6 may be part of this interaction (Mattacks \& Pond, 1999).

These facts demonstrate the linkage between adipose tissue and the immune system. As yet, it is not clear why such links exist. However, the immune system is a major user of energy (it has been estimated that it consumes about $15 \%$ of resting metabolic rate; about the same percentage as that of defence spending as a percentage of gross domestic product in the USA). One can therefore speculate that this level of energy usage needs to be linked to the availability of energy, especially the size of the adipose tissue energy stores. This requirement could explain the evolutionary development of 'cross-talk' between adipose tissue and the immune system. Such communication would need to be two way. When the immune system is stressed, it needs to call on energy from the stores, hence cytokines such as TNF- $\alpha$ have anti-adipogenic actions. Conversely, when the adipose tissue stores are undesirably small, signals that would reduce immunological preparedness and reduce energy expenditure would be appropriate. This type of communication is the likely origin of leptin and IL-6 as adipose tissues signals. Originally in evolution these proteins may have had a primary immunological message, but they may have evolved to become recognised by other tissues including the hypothalamus.

Although speculative, these reasons can explain why it is now becoming apparent, perhaps unexpectedly, that cytokines have important roles in adipose tissue. For adipose tissue biologists, cytokines are both a challenge and an opportunity. The challenge is to understand such a complicated and redundant system of regulation. The opportunity may be that they could offer a significant therapeutic target to combat the current expansion in the adipose tissue that we all are carrying around.

\section{References}

Bastard J-P, Jarde C, Bruckert E, Blondy P, Capeau J, Laville M, Vidal H \& Hainque B (2000) Elevated levels of interleukin 6 are reduced in serum and subcutaneous adipose tissue of obese women after weight loss. Journal of Clinical Endocrinology and Metabolism 85, 3338-3342.

Berkowitz DE, Brown D, Lee KM, Emala C, Palmer D, An Y \& Breslow M (1998) Endotoxin-induced alteration in the expression of leptin and $\beta_{3}$-adrenergic receptor in adipose tissue. American Journal of Physiology 274, E992-E997.

Beutler B, Krochin N, Milsark I, Leudke C \& Cerami A (1986) Control of cachexin (tumor necrosis factor) synthesis: mechanisms of endotoxin resistance. Science 232, 977-979.

Crawford EK, Ensor JE, Kalvakolanu I \& Hasday JD (1997) The role of $3^{\prime}$ poly(A) tail metabolism in tumor necrosis factor-alpha regulation. Journal of Biological Chemistry 272, 21120-21127.

Fawcett RL, Waechter AS, Williams LB, Zhang P, Louie R, Jones R, Inman M, Huse J \& Considine RV (2000) Tumor necrosis factor- $\alpha$ inhibits leptin production in subcutaneous and omental adipocytes from morbidly obese humans. Journal of Clinical Endocrinology and Metabolism 85, 530-535.

Feingold KR \& Grunfeld C (1992) Role of cytokines in inducing hyperlipidemia. Diabetes 41, Suppl. 2, 97-101.

Feingold KR, Staprans I, Memon RA, Moser AH, Shigenaga JK, Doerrler W, Dinarello CA \& Grunfeld C (1992) Endotoxin rapidly induces changes in lipid metabolism that produce hypertriglyceridemia: low doses stimulate hepatic triglyceride production while high doses inhibit clearance. Journal of Lipid Research 33, 1765-1776.

Fried SK, Bunkin DA \& Greenberg AS (1998) Omental and subcutaneous adipose tissues of obese subjects release interleukin-6: depot differences and regulation by glucocorticoid. Journal of Clinical Endocrinology and Metabolism 83, 847-850.

Fried SK \& Zechner R (1989) Cachectin/tumor necrosis factor decreases human adipose tissue lipoprotein lipase mRNA levels, synthesis, and activity. Journal of Lipid Research 30, 1917-1923.

Friedman JM (2000) Obesity in the new millennium. Nature 404, 632-634.

Gearing A, Beckett P, Christodoulou M, Churchill M, Clements J, Davidson AH, Drummond AH, Galloway WA, Gilbert R, Gordon JL, Leber TM, Mangan M, Miller K, Nayee P, Owen K, Patel S, Thomas W, Wells G, Wood LM \& Woolley K (1994) Processing of tumor necrosis factor- $\alpha$ precursor by metalloproteinases. Nature 370, 555-557.

Greenberg AS, Nordan RP, McIntosh J, Calvo JC, Scow RO \& Jablons D (1992) Interleukin 6 reduces lipoprotein lipase activity in adipose tissue of mice in vivo and in 3T3-L 1 adipocytes: a possible role for interleukin 6 in cancer cachexia. Cancer Research 52, 4113-4116.

Grunfeld C, Zhao J, Fuller J, Pollack A, Moser A, Friedman JE \& Feingold KR (1996) Endotoxin and cytokines induce expression of leptin, the $o b$ gene product, in hamsters. Journal of Clinical Investigation 97, 2152-2157.

Hardardottir I, Grunfeld C \& Feingold KR (1994) Effects of endotoxin and cytokines on lipid metabolism. Current Opinion in Lipidology 5, 207-215.

Hauner H, Bender M, Haastert B \& Hube F (1998) Plasma concentrations of soluble TNF-alpha receptors in obese patients. International Journal of Obesity and Related Metabolic Disorders 22, 1239-1243.

Hauner H, Petruschke T, Russ M \& Eckel J (1995) Effects of tumour necrosis factor alpha (TNF) on glucose transport and lipid metabolism of newly-differentiated human fat cells in cell culture. Diabetologia 38, 764-771.

Hotamisligil GS, (1999) The role of TNF $\alpha$ and TNF receptors in obesity and insulin resistance. Journal of Internal Medicine 245, 621-625.

Hotamisligil GS, Arner P, Atkinson RL \& Spiegelman BM (1997) Differential regulation of the $\mathrm{p} 80$ tumor necrosis factor receptor in human obesity and insulin resistance. Diabetes 46, 451-455.

Hotamisligil GS, Arner P, Caro JF, Atkinson RL \& Spiegelman BM (1995) Increased adipose tissue expression of tumor necrosis factor- $\alpha$ in human obesity and insulin resistance. Journal of Clinical Investigation 95, 2409-2415. 
Hotamisligil GS, Budavari A, Murray D \& Spiegelman BM (1994) Reduced tyrosine kinase activity of the insulin receptor in obesity-diabetes. Central role of tumor necrosis factor-alpha. Journal of Clinical Investigation 94, 1543-1549.

Hotamisligil GS, Johnson RS, Distel RJ, Ellis R, Papaioannou VE \& Spiegelman BM (1996a) Uncoupling of obesity from insulin resistance through a targetted mutation in $a P 2$, the adipocyte fatty acid binding protein. Science 274, 1377-1379.

Hotamisligil GS, Peraldi P, Budavari A, Ellis R, White MF \& Spiegelman BM (1996b) IRS-1-mediated inhibition of insulin receptor tyrosine kinase activity in TNF- $\alpha$-and obesity-induced insulin resistance. Science 271, 665-668.

Hotamisligil GS, Shargill NS \& Spiegelman BM (1993) Adipose expression of tumor necrosis factor- $\alpha$ : direct role in obesitylinked insulin resistance. Science 259, 87-91.

Hube F, Birgel M, Lee Y-M \& Hauner H (1999a) Expression pattern of tumour necrosis factor receptors in subcutaneous and omental human adipose tissue: role of obesity and non-insulin dependent diabetes mellitus. European Journal of Clinical Investigation 29, 672-678.

Hube F \& Hauner H (1999) The role of TNF- $\alpha$ in human adipose tissue: prevention of weight gain at the expense of insulin resistance. Hormone and Metabolic Research 31, 626-631.

Hube F, Lee Y-M, Rohrig K \& Hauner H (1999b) The phosphodiesterase inhibitor IBMX suppresses TNF- $\alpha$ expression in human adipocyte precursor cells: a possible explanation for its adipogenic effect. Hormone and Metabolic Research 31, 359-362.

Jain RG, Meredith MJ \& Pekala PH (1998) Tumor necrosis factoralpha mediated activation of signal transduction cascades and transcription factors in 3T3-L1 adipocytes. Advances in Enzyme Regulation 38, 333-347.

Jain RG, Phelps KD \& Pekala PH (1999) Tumor necrosis factoralpha initiated signal transduction in 3T3-L1 adipocytes. Journal of Cell Physiology 179, 58-66.

Jones JH \& Kennedy RI (1993) Cytokines and hypothalamicpituitary function. Cytokine 5, 531-538.

Jones TH (1994) Interleukin-6 an endocrine cytokine. Clinical Endocrinology 40, 703-713.

Kanety H, Hemi R, Papa MZ \& Karasik A (1996) Sphingomyelinase and ceramide suppress insulin-induced tyrosine phosphorylation of the insulin receptor substrate-1. Journal of Biological Chemistry 271, 9895-9897.

Kawakami M, Pekala PH, Lane DM \& Cerami A (1982) Lipoprotein lipase suppression in 3T3-L1 cells by an endotoxininduced mediator from exudate cells. Proceedings of the National Academy of Sciences USA 79, 912-916.

Kern PA, Saghizadeh M, Ong JM, Bosch RJ, Deem R \& Simsolo RB (1995) The expression of tumor necrosis factor in human adipose tissue. Regulation by obesity, weight loss, and relationship to lipoprotein lipase. Journal of Clinical Investigation 95, 2111-2119.

Kirchgessner TG, Uysal KT, Weisbrock SM, Marino MW \& Hotamisligil GS (1997) Tumor necrosis factor- $\alpha$ contributes to obesity-related hyperleptinemia by regulating leptin release from adipocytes. Journal of Clinical Investigation 100, 2777-2782.

Lawrence VJ \& Coppack SW (2000) The endocrine function of the fat cell - regulation by the sympathetic nervous system. Hormone and Metabolic Research 32, 453-467.

Ledgerwood EC, Prins JB, Bright NA, Johnson DR, Wolfreys K, Pober JS, O'Rahilly S \& Bradley JR (1998) Tumor necrosis factor is delivered to mitochondria where a tumor necrosis factor-binding protein is localised. Laboratory Investigation $\mathbf{7 8 ,}$ $1583-1589$

Liu LS, Spelleken M, Rohrig K, Hauner H \& Eckel J (1998) Tumour necrosis factor-alpha acutely inhibits insulin signaling in human adipocytes: implication of the p80 tumor necrosis factor receptor. Diabetes 47, 515-522.
McDermott MF (2001) TNF and TNFR biology in health and disease. Cellular and Molecular Biology (In the Press).

Mattacks CA \& Pond CM (1999) Interactions of noradrenalin and tumour necrosis factor $\alpha$, interleukin 4 and interleukin 6 in the control of lipolysis from adipocytes around lymph nodes. Cytokine 11, 334-346.

Mohamed-Ali V, Goodrick SJ, Bulmer K, Holley JMP, Yudkin JS \& Coppack SW (1999) Production of soluble tumor necrosis factor receptors by human subcutaneous adipose tissue in vivo. American Journal of Physiology 277, E971-E975.

Mohamed-Ali V, Goodrick SJ, Rawesh A, Miles JM, Katz DR, Yudkin JS, Klein S \& Coppack SW (1997) Subcutaneous adipose tissue secretes interleukin-6 but not tumour necrosis factor- $\alpha$ in vivo. Journal of Clinical Endocrinology and Metabolism 82, 4196-4200.

Mohamed-Ali V, Pinkney JH \& Coppack SW (1998) Adipose tissue as an endocrine and paracrine organ. International Journal of Obesity and Related Metabolic Disorders 22, $1145-1158$.

Montague CT, Prins JB, Sanders L, Zhang J, Sewter CP, Digby J, Byrne CD \& O'Rahilly S (1998) Depot-related gene expression in human subcutaneous and omental adipocytes. Diabetes $\mathbf{4 7}$, 1384-1391.

Morin CL, Eckel RH, Marcel T \& Pagliassotti MJ (1997a) High fat diets elevate adipose tissue-derived tumor necrosis factor-alpha activity. Endocrinology 138, 4665-4671.

Morin CL, Pagliassotti MJ, Windmiller D \& Eckel RH (1997b) Adipose tissue-derived tumor necrosis factor-alpha activity is elevated in older rats. Journal of Gerontology 52, B190-B195.

Mullberg J, Durie FH, Otten-Evans C, Alderson MR, Rose-John S, Cosman D, Black RA \& Mohler KM (1995) A metalloproteinase inhibitor blocks shedding of the IL-6 receptor and the p60 tumor necrosis factor receptor. Journal of Immunology 155, 5198-5205.

Niesler CU, Siddle K \& Prins JB (1998) Human preadipocytes display a depot-specific susceptibility to apoptosis. Diabetes $\mathbf{4 7}$, $1365-1368$.

Niesler CU, Urso B, Prins JB \& Siddle K (2000) IGF-1 inhibits apoptosis induced by serum withdrawal, but potentiates $\mathrm{TNF}-\alpha$-induced apoptosis in 3T3-L1 adipocytes. Journal of Endocrinology 167, 165-174.

Nisoli E, Briscini L, Giordano A, Tonello C, Weisbrock SM, Uysal KT, Cinti S, Carruba MO \& Hotamisligil GS (2000a) Tumor necrosis factor $\alpha$ mediates apoptosis of brown adipocytes and defective brown adipocyte function in obesity. Proceedings of the National Academy of Sciences USA 97, 8033-8038.

Nisoli E, Carruba MO, Tonello C, Macor C, Federspil G \& Vettor $\mathrm{R}(2000 b)$ Induction of fatty acid translocase/CD36, peroxisome proliferator-activated receptor- $\gamma 2$, leptin, uncoupling proteins 2 and 3 , and tumor necrosis factor- $\alpha$ gene expression in human sub-cutaneous fat by lipid infusion. Diabetes 49, 319-324.

Ofei F, Hurel S, Newkirk J, Sopwith M \& Taylor R (1996) Effects of an engineered human anti-TNF- $\alpha$ antibody (CDP571) on insulin sensitivity and glycemic control in patients with NIDDM. Diabetes 45, 881-885.

Ogawa H, Nielsen S \& Kawakami M (1989) Cachetin/tumor necrosis factor and interleukin-1 show different modes of combined effect on lipoprotein lipase and intracellular lipolysis. Biochimica et Biophysica Acta 1003, 131-135.

Papanicolaou DA, Wilder RL, Manolagas SC \& Chrousos GP (1998) The pathophysiologic roles of interleukin-6 in human disease. Annals of Internal Medicine 128, 127-137.

Pekala PH, Kawakami M, Angus CW, Lane MD \& Cerami A (1983) Selective inhibition of synthesis of enzymes for de novo fatty acid biosynthesis by an endotoxin-induced mediator from exudate cells. Proceedings of the National Academy of Sciences USA 80, 2743-2747. 
Peraldi P, Hotamisligil GS, Buurman WA, White MF \& Spiegelman BM (1997a) Tumor necrosis factor (TNF)- $\alpha$ inhibits insulin signalling through stimulation of the p55 TNF receptor and activation of sphingomyelinase. Journal of Biological Chemistry 271, 13018-13022.

Peraldi P, Xu M \& Spiegelman BM (1997b) Thiazolidinediones block tumor necrosis factor- $\alpha$-induced inhibition of insulin signaling. Journal of Clinical Investigation 100, 1863-1869.

Petruschke T \& Hauner H (1993) Tumor necrosis factor-alpha prevents the differentiation of human adipocyte precursor cells and causes delipidation of newly developed fat cells. Journal of Clinical Endocrinology and Metabolism 76, 742-747.

Plata-Salaman CR (2000) Central nervous system mechanisms contributing to the cachexia-anorexia syndrome. Nutrition 16, $1009-1012$.

Pond CM (1999) Physiological specialisation of adipose tissue. Progress in Lipid Research 38, 225-248.

Pond CM (2001) Long-term changes in adipose tissue in human disease. Proceedings of the Nutrition Society 60, 365-374.

Prins JB, Niesler CU, Winterford CM, Bright NA, Siddle K, O'Rahilly S, Walker NI \& Cameron DP (1997) Tumor necrosis factor- $\alpha$ induces apoptosis of human adipose cells. Diabetes $\mathbf{4 6}$, $1939-1944$.

Prins JB \& O'Rahilly S (1997) Regulation of adipose cell number in man. Clinical Science 92, 3-11.

Purohit A, Ghilchik MW, Duncan L, Wang DY, Singh A, Walker MM \& Reed MJ (1995) Aromatase activity and interleukin-6 production by normal and malignant breast tissues. Journal of Clinical Endocrinology and Metabolism 80, 3052-3058.

Qi C \& Pekala PH (2000) Tumor necrois factor- $\alpha$-induced insulin resistance in adipocytes. Proceedings of the Society for Experimental Biology and Medicine 223, 128-135.

Rothwell NJ (1994) CNS regulation of thermogenesis. Critical Reviews in Neurobiology 8, 1-10.

Saleh J, Summers LKM, Cianflone K, Fielding BA, Sniderman AD \& Frayn KN (1998) Coordinated release of acylation stimulating protein (ASP) and triacylglycerol clearance by human adipose tissue in vivo in the postprandial period. Journal of Lipid Research 39, 884-891.

Sarraf P, Frederich RC, Turner EM, Ma G, Jaskowiak NT, Rivet DJ 3rd, Flier JS, Lowell BB, Fraker DL \& Alexander HR (1997) Multiple cytokines and acute inflammation raise mouse leptin levels: potential role in inflammatory anorexia. Journal of Experimental Medicine 185, 171-175.

Sethi JK, Xu H, Uysal KT, Wiesbrock SM, Scheja L \& Hotamisligil GS (2000) Characterisation of receptor-specific TNFalpha functions in adipocyte cell lines lacking type 1 and 2 TNF receptors. FEBS Letters 469, 77-82.

Sewter CP, Digby JE, Blows F, Prins JB \& O’Rahilly S (1999) Regulation of tumour necrosis factor-alpha release from human adipose tissue in vitro. Journal of Endocrinology 163, 33-38.

Stephens JM, Butts MD \& Pekala PH (1992) Regulation of transcription factor mRNA accumulation during 3T3-L1 preadipocyte differentiation by tumor necrosis factor-alpha. Journal of Molecular Endocrinology 9, 61-72.

Stephens JM \& Pekala PH (1991) Transcriptional regression of the GLUT4 and C/EBP genes in 3T3-L1 adipocytes by tumor necrosis factor-alpha. Journal of Biological Chemistry 266, 21839-21845.

Strassmann G, Fong M, Windsor S \& Neta R (1993) The role of interleukin-6 in lipopolysaccharide-induced weight loss, hypoglycemia and fibrinogen production in vivo. Cytokine $\mathbf{5}$, $285-290$

Strosberg AD \& Pietri-Rouxel F (1996) Function and regulation of the beta3-adrenoceptor. Trends in Pharmacological Science 17, 373-381.

Sumida M, Shiosaka T, Nagar A, Isshikimasuda M, Okuda H \& Hamada M (1997) Suppressive effect of tumor necrosis factor- $\alpha$ on adipogenic cell differentiation and on gene expression of hormone-sensitive lipase. Journal of Clinical Biochemistry and Nutrition 22, 1-11.

Szalkowski D, White-Carrington S, Berger J \& Zhang B (1995) Antidiabetic thiazolidinediones block the inhibitory effect of tumour necrosis factor- $\alpha$ on differentiation, insulin-stimulated glucose uptake, and gene expression in 3T3-L1 cells. Endocrinology 136, 1474-1481.

Torti FM, Torti SV, Larrick JW \& Ringold GM (1989) Modulation of adipocyte differentiation by tumor necrosis factor and transforming growth factor. Journal of Cell Biology 108, 1105-1113.

Uysal KT, Wiesbrock SM \& Hotamisligil GS (1998) Functional analysis of tumor necrosis factor (TNF) receptors in TNF-alphamediated insulin resistance in genetic obesity. Endocrinology 139, 4832-4838.

Uysal KT, Wiesbrock SM, Marino MW \& Hotamisligil GS (1997) Protection from obesity-induced insulin resistance in mice lacking TNF- $\alpha$ function. Nature 389, 610-614.

Van der Poll T, Romijn JA, Endert E, Borm JJ, Büller HR \& Sauerwein HP (1991) TNF mimics the metabolic response of acute infections in healthy humans. American Journal of Physiology 261, E457-E465.

Ventre J, Doebber T, Wu M, MacNaul K, Stevens K, Pasparakis M, Kollias G \& Moller DE (1997) Targeted disruption of the tumour necrosis factor-alpha gene: metabolic consequences in obese and nonobese mice. Diabetes 46, 1526-1531.

Yudkin JS, Kumari M, Humphries SE \& Mohamed-Ali V (2000) Inflammation, obesity, stress and coronary heart disease: is interleukin-6 the link? Atherosclerosis 148, 209-214.

Zhang B, Berger J, Hu E, Szalkowski D, White-Carrington S, Spiegelman BM \& Moller DE (1996) Negative regulation of peroxisome proliferator-activated receptor- $\gamma$ gene expression contributes to the antiadipogenic effects of tumor necrosis factor- $\alpha$. Molecular Endocrinology 10, 1457-1466.

Zhang Y, Proenca R, Maffei M, Barone M, Leopold L \& Friedman JM (1994) Positional cloning of the mouse obese gene and its human homologue. Nature 372, 425-432 (published erratum appears in Nature 374, 479). 